\title{
O que é o Guia dos Bairros de Porto Alegre
}

\begin{abstract}
Adriana Dorfman *
Este guia foi elaborado pelos alunos do segundo ano do Ensino Médio do Colégio de Aplicação da UFRGS, como produto de uma disciplina de Enriquecimento Curricular oferecida no segundo semestre de 2008. Enriquecimento Curricular é um programa (em turno inverso ao das aulas) no qual os alunos desenvolvem atividades complementares que tem por objetivo integrar e articular o conhecimento das diversas matérias em um projeto. Observações sobre o programa da disciplina "Turismo na Grande Porto Alegre - bases geográficas" e sobre as explorações conceituais que deram origem ao Guia podem ser encontradas no artigo "Colocar-se diante do mundo: convergências pedagógicas entre Turismo e Geografia”, publicado neste mesmo número dos Cadernos do Aplicação.

A palavra guia remete justamente à ideia de um condutor, de algo que nos aponte caminhos e assinale pontos de observação e reflexão. Existem guias de viagem, guias espirituais, guias de projeto, guias de manutenção... Este guia em particular tem como temática a interface Geografia, Turismo e História da cidade de Porto Alegre, em especial de seus bairros. É um guia para se experienciar os lugares da cidade, contemplando-os, buscando perceber seus detalhes, mas também o modo como interagem e se interligam compondo esse todo que é o espaço urbano.

Nosso guia aborda dez bairros, para os quais são propostos rotas e trajetos de observação. São apontados marcos da memória dos bairros, elementos a serem observados como signos de sua
\end{abstract}

Professora Adjunta do Depto. de Geografia do IGEO-UFRGS. Mestre em Geografia pela UFRJ. Doutora em Geografia pela UFSC. E-mail: adriana.dorfman@gmail.com 
identidade e também fenômenos característicos dos arranjos espaciais urbanos e suas contradições.

Na Introdução cada bairro é apresentado em uma descrição geral de suas características, os elementos que lhes são particulares e lhe instituem uma identidade que o diferencia de outros bairros.

O Roteiro é um mapa que aponta os pontos a serem visitados, auxiliando a orientação dos visitantes. Além disso, agregamos uma breve informação sobre cada item destacado, e algumas fotos ilustrativas. Na seção Percorrendo listamos as linhas de transporte público que servem o bairro.

As Observações de Geografia Urbana indicam os fenômenos da espacialidade urbana de cada bairro que são interessantes de serem percebidos ao longo das visitas. 